\title{
In our name
}

\section{John Launer}

If you live in one of the big cities of the UK, including London, you may be familiar with the long white security vans that speed along our streets in the early morning and evening. Each of them has a few small darkened windows. You probably recognise them as prison vans. Like me, you may have assumed that the people inside were all suspected criminals on their way to court at the beginning of the day, or returning to custody at the end of it. In some cases, this may well be right. In other instances, the truth is rather different. The vans may be full of terrified, crying children. They are children who have been caught up in a system of hidden state brutality that puts us to shame.

The nature of this brutality has been described recently in precise but heartbreaking detail in a report by the Children's Commissioner for England, Professor Sir Al Aynsley-Green. ${ }^{1}$ In May 2008 he and a team of seven colleagues including a consultant paediatrician visited Yarl's Wood Immigration Centre in Bedfordshire, the main centre for families awaiting removal from the UK. It is run by a private security company under contract to the UK Borders Agency. Two thousand children are held in such centres each year, and, on the day of the visit, 54 children were present in Yarl's Wood. Fourteen were 1 year old or younger, 18 were between 2 and 5 years, and 22 were age 6 or over. Professor Aynsley-Green and his team spoke to over half of these children and many of these parents about the circumstances of their arrest, removal to the centre, and care during detention. They also investigated their healthcare while at the centre, including the arrangements for pregnant and nursing mothers, and their babies and infants. Every doctor in Britain-certainly every paediatrician and GP-should read the entire report of the visit, but let me summarise some of the information contained in it.

\section{OUT OF THE BLUE}

Most of the children and families awaiting deportation in Yarl's Wood are part of a huge backlog of asylum seekers who

Correspondence to: Dr John Launer, London Deanery, Stewart House, London WC1B 5DN, UK; jlauner@ londondeanery.ac.uk have been trapped in administrative limbo for years, while awaiting clarification of their uncertain immigration status. In consequence, they may have been in Britain for periods of up to 11 years, and many of the children have been born and had all of their schooling here. Arrest always comes completely out of the blue, with some families being seized while on a routine visit to an immigration office to sign on, although most are arrested at home first thing in the morning, in quite shocking ways. When the visiting team interviewed them singly and in groups, the children described how they first heard knocking at the front door. It was "very loud", "loud hammering", "fierce", "terrifying". Some children were asleep when the officers arrived, and thus were woken by strangers. One couple with two children under 5 reported to the team how over 20 officers turned up to arrest her. A single woman with a 1-year-old had 10 officers turn up to arrest her.

In a large majority of cases, children reported that officers had been aggressive, rude and, on a few occasions, violent. One child had bruises where he had been restrained, while others had been grabbed, dragged and manhandled. Another child asked the team: "Why did they have to search my sister? She is only five." Some children described officers taking pleasure in the family's distress, including telling them that they were "going back to their own country" and laughing and making fun of them when they showed signs of distress or anxiety.

\section{LEAVING PETS AND FRIENDS BEHIND}

In many cases, families were given only minutes to pack, and forced to leave behind their pets, toys, shoes, CDs, clothes, jewellery, books and even medication. One family with two children suffering from sickle-cell anaemia was prevented from collecting antibiotics and folic acid. Some were not allowed to eat and drink, or even to go to the toilet, except in front of officers of the opposite sex. Others were forced to surrender their mobile phones or leave them behind. "Children were most anxious", the report states "about being placed in separate vans from a parent and having their phones confiscated so they could not communicate with them".
The vans in question are described by the children in nightmarish terms. "Why do they have to put us in cages?" asked one girl aged 11. Other children said they were "airless", "dirty", "stinking of urine", and "stained with urine and vomit". Many children complained of the lack of any food and drink, or any information about where they were going and how long it would take. Some lost control of their bladder and bowels. They told of how the security guards laughed at them, talked about inappropriate or offensive things and swore a lot.

On arrival at Yarl's Wood, the children realise it is a prison. Professor AynsleyGreen describes it as "bleak and grey". The environment, including the concrete play area, is "stark and lacks warmth and comfort". The imprisoned children miss their schools and their friends-whom they are unable to contact to explain their disappearance. They lack privacy, and even night-time showers can be interrupted for a roll-call, presumably to make sure no-one has escaped. Food is repetitive and monotonous. Equipment is inadequate. "A simple request to pump up the balls used in activities, not a major resource issue, was raised...over more than a year, suggesting that little was done to remedy the situation." The children and their families may stay in Yarl's Wood for a week, a month, or over a year while they await a further legal process, a temporary release, or sudden deportation to a country in Asia or Africa they have never known - and where their parents may once have been tortured, raped or persecuted. Many of the children become withdrawn and depressed.

\section{UNACCEPTABLY POOR}

However distressed we may be by the details of these children's arrest and detention, it is the poor medical care described in the Yarl's Wood report that should perhaps most concern us. At the time of the Commissioner's visit, this was provided by a rota of locum general practitioners, seeing patients without their past medical records and with little time to assess healthcare needs. The inspecting team analysed healthcare records and found that requests for information from the child's previous GP was sought in only two out of 42 cases. In neither case was there any response. Only one case showed evidence that anyone had seen a child's "Red Book" (the standard national health record for children.) No paediatricians had been called in to see any of the sample cases, although 
they had conditions including sickle cell anaemia, insulin-dependent diabetes, asthma, eczema or a parent with HIV infection. According to the report, the doctors are failing to certify children as unfit for detention, let alone deportation, even when this is patently the case.

The team found no evidence of audit, use of clinical guidelines for children, or clinical incident reporting. Their analysis showed that there was no appropriate assessment of children's mental health. Immunisation was not given to two of the three children who were identified by healthcare staff as needing it, and the third child was given the wrong vaccine. There was no record of any child being immunised against measles at the appropriate age, no meningococcal vaccine was given to any of the 14 children who required it, and no child was administered with BCG in spite of the very high risk of tuberculosis on removal. The team felt that the use of the term "not applicable" in some children's records "raises questions regarding health workers understanding of the life-saving potential for this immunisation".

The only published guidelines that the team could discover at the centre were for the prevention of malaria, but this guidance contradicted standard advice and was "unacceptably poor", containing a number of "serious errors". Examination of the notes of 14 children due to be deported to Africa showed that none had even received the care stated by the guidance. Prophylaxis was actually administered to only two of the children and neither prescription was correct. With regard to the care of mothers and infants, provision of milk supplements, bottle equipment and vitamin and mineral supplements for mothers and infants was observed to be quite inadequate. "Formula is either rationed or difficult to get hold of". The bottle warmers "represent a serious health risk to mother". Altogether, arrangements are "unsatisfactory and are likely to be contributing to the high levels of infant illness found in Yarl's Wood". An audit of medical records failed to indicate that any vitamin supplementation had been given to any pregnant women. The report cites the case of a breast-fed infant aged 9 months who was detained for 4 months and released suffering from both anaemia and rickets.

\section{ALARMING CASES}

This particular case is only one of many alarming ones. One child who became ill was transferred to Bedford Hospital and found to have a central venous line in place, although the Yarl's Wood doctors had evidently been unaware of it. A brother and sister with sickle cell disease had their penicillin treatment interrupted. When they became unwell with high fevers, the health centre prescribed paracetamol and oral fluids. Professor Aynsley-Green comments that "this appears to amount to a failure of care which, in NHS services, would be viewed as a "near miss"'. This would require investigation as a potentially life-threatening "Serious Untoward Incident". There are similar examples relating to mental healthcare. In the case of a mother who was known to have a severe depressive illness with auditory hallucinations, and who was a victim of torture, her 2year old son was merely described as "a happy boy". A teenager admitted to hospital after threatening suicide was guarded on an open ward by four security officers.

The report comments that "the current situation is one where Serco Health has been operating health care services without clinical governance of a reasonable standard for around 18 months". The report makes no reference to the professional duties of the individual doctors concerned. Diplomatically, and perhaps pragmatically, Professor Aynsley-Green confines his recommendations to administrative ones. Detention of children for administrative reasons under immigration law, he proposes, should now end. Exceptional circumstances for detention must be clearly defined and should be in line with the United Nations Convention on the Rights of the Child. The UK Borders Agency should develop community-based alternatives to detention. While these are being implemented, all children should be treated in compliance with the government's own principles as set out in its document "Every child matters". The government should monitor compliance with UN standards. Above all, the UK Borders Agency should set out the responsibilities and accountabilities of all agencies involved including the providers of security and healthcare.

One proposal that is not in the report is that the representative bodies of our own profession, including the British Medical Association and General Medical Council, must shoulder their responsibilities in relation to what is happening at Yarl's Wood. I believe they should. These brutalities are being carried out in our name, and they implicate us all, both as UK citizens and as doctors.

\section{Competing interests: None.}

Postgrad Med J 2009;85:447-448.

doi:10.1136/pgmj.2009.085688

\section{REFERENCE}

1. $\mathbf{1 1}$ million. The arrest and detention of children subject to immigration control: a report following the Children's Commissioner for England's visit to the Yarl's Wood Immigration Removal Centre. London: 11 million, 2009. http://www.11million.org.uk/resource/ di550e08psxhlc9f3mmrlqwd.pdf (accessed 24 Jun 2009). 